\title{
ASSESSMENT OF PERCEIVED FACTORS INFLUENCING TEACHING AND LEARNING IN SELECTED TERTIARY INSTITUTIONS IN BAYELSA STATE
}

\author{
MEMORY QUEENSOAP ${ }^{1 *}$, PhD, DOGITIMIYE MEMORY ${ }^{2}$, JOY BEDFORD \\ OSOKOLO $^{3}$, AYEBANENGIMOTE VICTOR ${ }^{2}$ AND MESHACH GBAYE ${ }^{2}$ \\ ${ }^{1}$ Department of Arts Education, Faculty of Education, Federal University Otueke, Bayelsa State \\ ${ }^{2}$ Department of Health Information Management, Bayelsa State College of Health Technology, \\ Otuogidi, Ogbia-Town. \\ ${ }^{3}$ Department of Community Health Sciences, Bayelsa State College of Health Technology, Otuogidi, \\ Ogbia-Town.
}

https://doi.org/10.37602/IJSSMR.2020.3307

\begin{abstract}
The need to have effective teaching and learning is a concern to every stakeholder in the educational sector. The outcome of effective teaching and learning is a corresponding academic performance of students and thus this study aimed at assessing perceived factors influencing teaching and learning in selected Tertiary Institutions in Bayelsa State. This study, through proportional stratified random sampling technique and convenience sampling technique, selected a sample size of 324 from 1683 in Bayelsa State College of Health Technology (BSCHT) and Bayelsa State School of Nursing (BSSON). The study adopted a descriptive research design. Data were obtained with self-designed instruments (SPFITHI \& SPFILHI) and data analysis was done with Microsoft Excel 2010 and Prism Graph Pad 5. It was revealed that among perceived factors influencing teaching, physical factors were most influential with grand mean, standard deviation and percentage mean of $3.32 \pm 0.82$ and $83 \%$. Perceived factors influencing learning mostly were received by physical factors $(3.36 \pm$ $0.84 \& 83.9 \%$ ). Other factors affecting teaching such as socio-cultural and mental factors received $2.99 \pm 0.89$ with $74.8 \%$ and $3.19 \pm 0.73$ with $79.8 \%$ respectively while those factors affecting learning other than the physical factors received $3.26 \pm 0.88(81.74 \%)$ and $3.15 \pm$ 0.82 (78.8) for socio-cultural and mental factors. Result reveals that all perceived factors affect teaching and learning at a very high extent. All the null hypotheses tested were not significant, indicating that in as much as the perceived factors remain, independent to institutions respondent perceived them similarly at different institutions as they affect teaching and learning. The study concludes that the perceived factors influencing teaching and learning can be grouped as socio-cultural, physical cum mental factors. Based on this, recommendations were made, among which is the government should partner with the private sector to allocate adequate space, budgets for supplies, professional resources, equipment and overheads to tertiary institutions.
\end{abstract}

Keywords: Teaching, Learning, physical factors, socio-cultural factors, and mental factor. 


\section{International Journal of Social Sciences and Management Review}

\subsection{INTRODUCTION}

Generally, giving quality education to every individual is a task to every well-meaning government which is taken as an indispensable responsibility. This is geared towards reducing world illiteracy among citizens. Education is seen as an instrument par excellence to change of behaviour and performance (the Federal Republic of Nigeria, 2004). Every government owes her citizens a quality education. Quality education is seen as providing an affordable and stress-free educational system to the people. Nigeria has made it as compulsory for every child to have primary education at least (FRN).

According to (Onuebunwa, 1999), quality education consists of effective teaching and learning. Teaching is the act, practise or profession of a teacher. Teaching involves a person in an experience that brings about desirable changes in ability and behaviour while the word learning is a relatively permanent change in behaviour due to experience as alluded to by (Coon, 2003).

(Philip, 2007), suggested that learning is a consequence of experience, he argued that education and teaching should be a focus on the creation of appropriately nourishing experience so that learning comes naturally and enviably. Among other measures, the standard of education is mostly measured by students' academic performance. Hence, the essence of good classroom teaching is the ability to create an environment that can mobilize the learner to pursue the curriculum and then can maintain that mobilization, while effectively facilitating learning. The process, of course, is met not only to teach academics but to turn out good citizens (Aldelman \& Talylor, 2006).

Skeff and his colleagues in (DaRosa, et al., 2011) noted several phenomena that hinder effective teaching, this includes curricular, cultural, environmental, and financial barriers. They stated that unclear learning needs such as curricular barriers affect learning and teaching, cultural barriers and effective teachings refer to the attitudes, traditions and mores of health institutions. The identified environmental barriers also include time, space, instrumental human and technological resources. Revenues and resources needed in health institutions as financial barriers have been observed as factors affecting teaching and learning, these above ideologies where expressed (DaRosa, et al., 2011).

Boles (2007), has found out that the educational environment, behaviours and actions, individual attitudes are factors affecting student learning. In the educational environment according to Boles, student experiences influence their behaviour and their perceptions of themselves and their capabilities. For example, receiving no feed-back on their learning can lead students to assume that they are doing well when they are leading to failure and a drop in academic confidence.

Learning can often be like an obstacle for students while for some this is an exciting challenge leading them toward the finishing line of graduation and achievement of their carrier aspirations, but this is not always the case. Sometimes these obstacles can become so large a challenge that some students fall by the wayside, either failing or choosing to leave their course of study. The question that those who teach should ponder is 'What factors contribute to students not making it or performing less than their best?' (Boles, 2010). 


\section{International Journal of Social Sciences and Management Review}

Students' academic performance is a concern for students, teachers, parents and all stakeholders of child education. There are revealed trends of poor/low academic performance despite the efforts of the school management, government, teachers, parents and even students themselves. Previous studies had observed that there are several factors affecting students' academic performances which are peculiar to an extent to the institution.

Nevertheless, most of these documentations are seen in the secular universities and some institutions such as colleges of education, colleges of Health Technology, polytechnics, etc. are left out. Therefore, this work is to assess perceived factors affecting teaching and learning in selected tertiary institutions, precisely health institutions.

\subsection{LITERATURE REVIEW}

Teaching involves a person in and experience that brings about desirable changes in abilities and behaviour (Onuebunwa, 1999). Learning is a process of growth, progress and improvement during which and individual acquires knowledge, habits, skills, and attitude (Edoghotu \& Adu, 2014). In the light of (Strokes, 2007) "Learning"' is not a passive, knowledge consuming and externally directed process, but active, constructive self-directed process in which learners build up internal knowledge representation that is a personal interpretation of their learning experience.

Therefore, teaching is an attempt to bring about desirable changes in human learning. The aim of teaching is to influence the learners to make those desired changes in their behaviour that contribute to better living and involving the learner in activities that would give them experience, that would produce learning, not merely going through the motion of teaching.

Learning becomes more perfect when theoretical knowledge is supplemented by learning all possible, life-supporting skill. Learning more and more life skills increases the strength of the learning skills and seeking a challenging situation to engage these skills are what lead to meaningful learning.

By the idea of (Edoghotu \& Adu, 2014) Students experiencing difficulty in grasping a particular concept can lead to apparent blockage in their learning which is only cleared when the student finally gains the necessary understanding to proceed. With some concept, this can be a straight forward process requiring only and alternative explanation or carefully worked example to smooth the way for continued learning with other concepts, however, the learning of this mental blockage has a much more significant and fundamental impact with the resulting understanding of insight opening up a wide new way of thinking and practising in a discipline.

Teaching-Learning is measured mostly by the academic performances of students. Academic performance is the outcome of education, the event to which a student, teacher or institute has achieved their educational goals. Academic performance is commonly measured by examination or continuous assessment but there is no general agreement on how it is to be tested or which aspects are most important procedure such as skill or declaration of knowledge such as facts. 


\section{International Journal of Social Sciences and Management Review}

Academic success is no doubt the main focus of all academic activities. Academic is concerned with studying especially at college or university level (Mayor, 2009). Mayor defined success as when one achieves what he/she wants or intends. This implies to the study that academic success denotes achievement in the course or at the end of a study at a college or university level by a student. The (Federal Republic of Nigeria, 2004) presented academic success as performance or achievement. That is to say academic achievement refers to grade in report cards used at the end of a period indicating to student their performance in various academic subjects.

To (Ward, Stoker, \& Murray-Ward, 1996), academic achievement is the outcome of the education-the extent to which a student, teacher or institution has achieved their educational goal. Similarly, (Bell, n.d) defined academic performance in educational institutions as a success measured by how well a student meets standards set out by the institution. This definition points to the student being awarded in character and in learning at the end of the program of study.

Accordingly, the International Association for the Evaluation of Education Performance, more often than a standardized test score or examination results are used to determine how well students are doing in school. In Nigeria however, standardize testing are taken for granted (Queensoap, 2014). The general population does not question whether, or not these measures are valid ways to assess their children development and learning. In reality, therefore, these tests are determinants of accountability, a term used by those in power who need to know how effective the system works. But should schools be so hooked on standardized test for student?

(Warash, 1996), have pointed out the inadequacies of mixing a more holistic curriculum with traditional pencil and paper assessment tools. The author makes a strong argument for looking beyond the traditional evaluation methods. Furthermore, (Gardner, 1993)also agrees that academic performances should be measured in various ways. The assessment then becomes a central feature of an educational system. We believe that it is essential to depart from standardized testing.

Academic performance is an outcome of the process of teaching and learning. It has been observed in the available literature that performance is influenced by various factors such as Ordinary level subjects' scores and subjects' combination; Matriculation examination scores; Age on admission; Parental background; Types and location of secondary school attended, Gender etc.(Oladokun, Adebanjo, \& Charles-Owaba, 2008).

Literature available identified the followings as factors that have a major influence on teaching and learning.

\subsection{Teacher Quality}

In bringing about the desired behavioural changes in learners, the teacher is a vital factor in success in any educational system. Its successes or failure is to a large extent dependent on how good or bad the teacher is at playing his /her role. 


\section{International Journal of Social Sciences and Management Review}

Effective teaching which brings about learning and achievement of stipulated objectives does not occur as a result of how much information the teacher passes on the leaner. It is as adjust instruction to all groups of the learner to fit specific purposes, using methods, materials and content. Thus, an effective teacher is one who is knowledgeable in his area of speciality, practices what he/she theorizes, as well as competent in the art of teaching as in the view of (Steinke \& Putman, 2007). The article established that teacher quality is one of the most influential factors that were perceived by respondents in their study.

\subsection{Behaviours and Action}

This refers to what the students do about their learning. According to (Center for Mental health in schools, 2008) students attitudes and expectations were the single greatest barrier to the implementation of critical-thinking teaching strategies, in that students prefer lecturers over instructional strategies that require active learning. Some students expect the department to deliver content through a method that makes for easier memorization, which some students feel is critical for passing information dense examinations. Such "spoon-feeding" constrains teachers from emphasizing reflection and curiosity rather than short term memorization.

\subsection{Curricular Barriers}

(DaRosa, et al., 2011), noted several phenomena that hinders effective clinical teaching, among others are that instructors are too often expected to address a wide range of educational goals that are unachievable given not only the clinical setting and limited time allotted but also the variability of learners previous knowledge and experience.

The random curriculum sequencing of clinical experiment inherent in clinical education makes for chaotic and inconsistent learning and assessment. Teachers need time with their learners to know their capabilities, to reinforce strength and to address weakness and skills, since much remains to be done in this area, including both standard core goals and objectives and developing a complementary performance evaluation system that assesses students' proficiency in a way that tracks the change in their knowledge and understanding over time. Time together is critical to establish the teacher-student bond that makes teaching and learning rewarding and meaningful as opined by (Irby, Cooke, \& O'Brien, 2010).

Students rotate among multiple clerkships but not necessarily in a uniform sequence. The variety of pathways for learner may seem positive given the flexibility, but for those responsible for teaching, this lack of uniformity poses a significant challenge. The clinical curriculum becomes a "catch as catch can" teaching experience which is inconsistent and impedes the repetition of clinical experience that serves to improve and deepen skills, concepts, and problem integration.

\subsection{Cultural Barriers}

Cultural barriers to effective teaching refer to the attitudes, traditions and more of medical schools including students' faculty and hospital leaders, remarked Stern and Hafferty in (DaRosa, et al., 2011). 


\section{International Journal of Social Sciences and Management Review}

Faculty attitudes/Teachers behaviour: Teachers attitudes toward teaching and toward department development for improving teaching skills are also barriers to effective teaching. Teachers often lack belief in their usefulness or importance of department development because they underestimate the need for it and or the potential it has to improve their teaching. Some instructors overestimate their teaching strengths and believe being a good clinician or basic scientist is all that is required in order to be an effective teacher, not recognizing teaching itself as a discipline to be mastered said (Friedland, 2002).

Studies have shown that teachers may think they are good teachers, without formal preparation for that role, they can at the same time lack the confidence needed to use unfamiliar teaching skills beyond traditional methods or in one's ability to teach certain topics impedes creative and novel instruction. Faculty commonly identifies both the absence of formal training on teaching and the lack of protected time to participate in the programs that do exist. Hence, Faculty attitudes also influence performance evaluation outcomes and compliance. It was further observed that faculty members tend not to fail learners, even when they deserve to fail. This was asserted in Dudek, et al., in (DaRosa, et al., 2011).

Institutional support need to the teaching faculty, feel the support of their institution and accreditation agencies against malpractice litigation, faculty report that because of the perceived prevalence of lawsuits and claims made against physicians, they increase their supervision, give learners less autonomy inpatient care, limit opportunities for learners to deliver. Institutions need to explicitly address malpractice and teaching to clarify the issues and help faculty effectively manage both teaching and clinical care responsibilities, (DaRosa, et al., 2011).

Search committees rarely consider either teaching expertise or enthusiasm for teaching when appointing new faculty members. This lack of forethought is due largely to the difficulty of measuring these attributes and the frequency of using education portfolios for reviews, search committee also rarely discuss the teaching abilities of new faculty member hires, rather they assume that new faculty members will teach and have their skills to do so. This assumption perpetuates the practice of hiring faculty members, who may not have a passion for teaching, who may view teaching, as something to do only when time permits and who may have poor teaching skill, (Friedland, 2002).

\subsection{Educational Environment}

In consonant with (Philip, 2007), the educational environment is the most important area of academic influence. It encompasses the following areas:

- Physical Space and Settings: The physical space and settings that are necessary to support the then educational mission are not always integrated into facilities plan processes, thereby causing insufficient or inappropriately designed physical space for teaching and inconsistent access educational specialist, which are environmental barriers to effective teaching and learning (Oladokun, et al., 2008). 


\section{International Journal of Social Sciences and Management Review}

Volume: 03, Issue: 03 "May - June 2020"

ISSN 2582-0176

- Campus Environment: This contributes to students' engagement with the physical or virtual location of their learning. This also includes the extent to which the campus environment supports students to work together or form a learning community (Gibbs \& Simpson, 2005).

- Classroom Climate: This refers to the arrangement of seats, teaching aids, nature of teacher-student interaction, the teaching/learning activities and student learning feedback. It is essential for teachers to be aware that students could not progress well if they are learning in a discordant and non-organized classroom atmosphere as expressed by (Edoghotu \& Adu, 2014).

\subsection{METHODS}

A descriptive survey research design was adopted for the study. This design was appropriate for the study because it enabled the researcher to collect data at its natural setting and summarize, analyze and interpret so as to achieve the aim of the study. The researchers selected Bayelsa College of Health Technology (BSCHT) and Bayelsa State School of Nursing (BSSON) as a tertiary institution for the study.

The population of this study consisted of students and academic staff of both institutions. The college of health technology has 118 and 1373 academic staff and students respectively while the School of Nursing has 23 academic staff and 169 students. Therefore the study population stood at 1683 (Registry of the college and Principals' office of school of Nursing). Based on the population of the study, a Taro Yamen's sampling size determination formula was used to determine the sample size of the study to be 324 . The sampling technique adopted was a proportional stratified sampling technique. This random sampling technique enabled the researcher to divide the study population into the different constituents of the population as strata. The sample drawn from BSCHT was 287 while BSSON contributed 37, bringing the total sample size to 324 . The researcher also adopted a convenience sampling technique to get the research instruments administered. The researchers designed two instruments for academic staff and students. The study instruments were made valid through the face and content validity methods of validation of instruments and they were made reliable through Cronbach alpha reliability determination procedure. The reliability coefficients of the study instruments were .75 and .79 for academic staff and students respectively. Data obtained were presented with a table, a pie chart and a simple percentage. The analysis was done with mean, standard deviation and correlation statistics as well as Independent Sample Test Excel Microsoft word was used to present data in pie chart while Prism Graph Pad 5 was used in analyzing data. Ethical consideration was taken care of by the researchers.

\subsection{RESULTS/DISCUSSION}

4.1 Which are, the perceived socio-physical cum mental factors influencing Teaching in Health Institutions?

Table 1: Summary of Mean, Standard Deviation and Percentage Mean Analysis on Perceived factors affecting Teaching. 


\section{International Journal of Social Sciences and Management Review}

Volume: 03, Issue: 03 "May - June 2020"

ISSN 2582-0176

\begin{tabular}{|c|c|c|c|c|c|}
\hline $\begin{array}{l}\text { Item } \\
\text { Number/ } \\
\text { factors }\end{array}$ & Number $(\mathbf{N})$ & Mean & $\begin{array}{l}\text { Stand. } \\
\text { deviation }\end{array}$ & $\begin{array}{l}\text { Percentage } \\
\text { Mean }\end{array}$ & $\begin{array}{l}\text { Criterion } \\
\text { Mean }\end{array}$ \\
\hline \multicolumn{6}{|l|}{$\begin{array}{l}\text { Socio- } \\
\text { cultural }\end{array}$} \\
\hline 1 & 25 & 3.32 & 0.79 & 83 & \multirow{6}{*}{2.5} \\
\hline 2 & 25 & 3.2 & 0.98 & 80 & \\
\hline 3 & 25 & 2.56 & 1.17 & 64 & \\
\hline 4 & 25 & 2.96 & 0.60 & 74 & \\
\hline 5 & 25 & 2.92 & 0.89 & 73 & \\
\hline $\begin{array}{l}\text { Grand } \\
\text { Values }\end{array}$ & & 2.99 & 0.89 & 74.8 & \\
\hline \multicolumn{6}{|l|}{$\begin{array}{l}\text { Physical } \\
\text { factors }\end{array}$} \\
\hline 6 & 25 & 3.48 & 0.70 & 87 & \multirow{7}{*}{2.5} \\
\hline 7 & 25 & 3.0 & 0.98 & 75 & \\
\hline 8 & 25 & 3.4 & 0.57 & 85 & \\
\hline 9 & 25 & 3.36 & 0.89 & 84 & \\
\hline 10 & 25 & 3.36 & 0.97 & 84 & \\
\hline $\begin{array}{l}\text { Grand } \\
\text { values }\end{array}$ & & 3.32 & 0.82 & 83 & \\
\hline \multicolumn{5}{|l|}{$\begin{array}{l}\text { Mental } \\
\text { Factors }\end{array}$} & \\
\hline 11 & 25 & 3.4 & 0.63 & 85 & \multirow{6}{*}{2.5} \\
\hline 12 & 25 & 3.08 & 0.75 & 77 & \\
\hline 13 & 25 & 3.44 & 0.75 & 86 & \\
\hline 14 & 25 & 2.92 & 0.79 & 73 & \\
\hline 15 & 25 & 3.12 & 0.71 & 78 & \\
\hline $\begin{array}{l}\text { Grand } \\
\text { Values }\end{array}$ & & 3.19 & 0.73 & 79.8 & \\
\hline
\end{tabular}

A critical look at Table 2 above indicated that there were, socio-physical cum mental factors perceived to have influence teaching in health institutions. Table 2 presented all perceived factors investigated above the criterion mean of 2.5, implying that all the factors listed influence teaching in the respective Institutions under study. In fact, Physical Factors pose the highest influence on teaching, followed by Mental Factors and then Socio-cultural Factors which presented a percentage mean influence of $83 \%, 79.8 \%$ and $74.8 \%$ respectively.

4.2 Which are, the perceived socio-physical cum mental factors influencing learning in Health Institutions?

Table 3: Summary of Mean, Standard Deviation and Percentage Mean Analysis on Perceived factors affecting Learning

\begin{tabular}{|c|c|c|c|c|}
\hline $\begin{array}{l}\text { Item } \\
\text { Number/ }\end{array}$ & Number (N) Mean & $\begin{array}{l}\text { Stand. } \\
\text { deviation }\end{array}$ & $\begin{array}{l}\text { Percentage } \\
\text { Mean }\end{array}$ & $\begin{array}{l}\text { Criterion } \\
\text { Mean }\end{array}$ \\
\hline
\end{tabular}




\section{International Journal of Social Sciences and Management Review}

Volume: 03, Issue: 03 “May - June 2020”

ISSN 2582-0176

\begin{tabular}{|c|c|c|c|c|c|}
\hline \multicolumn{6}{|l|}{ factors } \\
\hline $\begin{array}{l}\text { Socio- } \\
\text { cultura }\end{array}$ & & & & & \multirow{7}{*}{2.5} \\
\hline 1 & 271 & 3.50 & 0.72 & 87.5 & \\
\hline 2 & 271 & 2.96 & 0.94 & 74 & \\
\hline 3 & 271 & 3.14 & 0.79 & 78.5 & \\
\hline 4 & 271 & 3.28 & 1.06 & 82 & \\
\hline 5 & 271 & 3.43 & 0.87 & 86.7 & \\
\hline $\begin{array}{l}\text { Grand } \\
\text { Values }\end{array}$ & & 3.26 & 0.88 & 81.74 & \\
\hline \multicolumn{6}{|c|}{$\begin{array}{l}\text { Physical } \\
\text { factors }\end{array}$} \\
\hline 6 & 271 & 3.42 & 0.79 & 85 & \multirow{7}{*}{2.5} \\
\hline 7 & 271 & 3.48 & 0.74 & 87 & \\
\hline 8 & 271 & 3.34 & 0.71 & 83.5 & \\
\hline 9 & 271 & 3.29 & 0.95 & 82.2 & \\
\hline 10 & 271 & 3.27 & 0.83 & 81.7 & \\
\hline $\begin{array}{l}\text { Grand } \\
\text { values }\end{array}$ & & 3.36 & 0.84 & 83.9 & \\
\hline \multicolumn{5}{|c|}{$\begin{array}{l}\text { Mental } \\
\text { Factors }\end{array}$} & \\
\hline 11 & 271 & 3.20 & 0.94 & 80 & \multirow{6}{*}{2.5} \\
\hline 12 & 271 & 2.89 & 0.88 & 72.2 & \\
\hline 13 & 271 & 3.23 & 0.67 & 80.7 & \\
\hline 14 & 271 & 2.81 & 0.94 & 70.2 & \\
\hline 15 & 271 & 3.63 & 0.65 & 90.7 & \\
\hline $\begin{array}{l}\text { Grand } \\
\text { Values }\end{array}$ & & 3.15 & 0.82 & 78.8 & \\
\hline
\end{tabular}

Table 3 above presented grand mean, standard deviation and percentage mean of 3.26, 0.88 and 81.74 for socio-cultural factors respectively while 3.36, 0.84 and 83.9 are for physical factors respectively; and Mental Factors rate of influence was 3.15 (mean), 0.82 (stand. deviation) and 78.8 (percentage mean) (appendix G). This indicates that Physical factors had more influence on learning than other factors. Meanwhile, all the factors under investigation scored a mean above the criterion mean of 2.5 , meaning that they are all perceived factors influencing learning in the Health Institutions in Bayelsa State.

4.3 To what extent do perceive factors influencing teaching and learning in Health Institutions related? 


\section{International Journal of Social Sciences and Management Review}

Volume: 03, Issue: 03 "May - June 2020"

ISSN 2582-0176

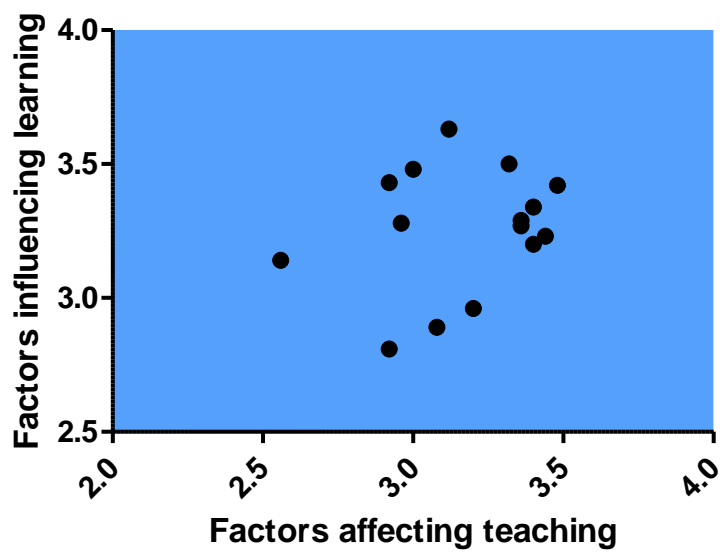

Figure 4: A Scatter diagram showing the extent of the relationship between factors affecting teaching and learning.

Table 4: Summary of Correlation Statistics

\begin{tabular}{lrllllll}
\hline \multicolumn{2}{l}{ Correlation Pairs } & $\begin{array}{l}\text { Number } \\
\text { Pairs }\end{array}$ & of & XY & Pearson r & $\begin{array}{l}\text { R } \\
\text { Square }\end{array}$ & \% R \\
\hline $\begin{array}{l}\text { Factors } \\
\text { teaching } \\
\text { learning }\end{array}$ & $\begin{array}{r}\text { affecting } \\
\text { and }\end{array}$ & 15 & & .23 & .054 & $5.4 \%$ \\
\hline
\end{tabular}

Figure 4 and Table 4 presented a Pearson (r) as .23; R square is .054 while $\mathrm{R}$ percentage is $5.4 \%$. This indicates that perceived factors influencing teaching and learning in Health Institutions in Bayelsa State are related to the extent of 5.4\%. It implies therefore that there is zero or little relationship. The factors are independent to their institutions.

\subsection{Null Hypothesis 1}

There is no significant difference between mean responses of BYCOHTECH Staff and BYSSON Staff on perceived factors influencing teaching and learning Health Institution.

Table 5: Summary of Independent Sample Test

\begin{tabular}{lllllllll}
\hline Variables & N & Mean & $\begin{array}{l}\text { Stand. } \\
\text { deviation }\end{array}$ & T & Df & $\begin{array}{l}\text { Sig. (2- } \\
\text { tailed) }\end{array}$ & P>.05 & Decision \\
\hline $\begin{array}{l}\text { BYCOHTECH } \\
\text { Staff }\end{array}$ & 21 & 46 & 6.6 & .20 & 23 & .84 & Ns & $\mathrm{H}_{\mathrm{o}}$ \\
BYSSON Staff & 4 & 47 & 5.2 & & & & & accepted \\
\hline
\end{tabular}

Table 5 above showed that BYCOHTECH Staff consisted of 21 respondents $(\mathrm{N}), 46 \pm 6.6$, mean and standard deviation respectively while BYSSON Staff has 4 respondents, $47 \pm 5.2$, mean and standard deviation respectively. It can be observed from table 5 that $t$ ratio has .20 , degrees of freedom of 23, P-value (Sig. for 2-tailed) of .84 which is greater than .05 alpha. 


\section{International Journal of Social Sciences and Management Review}

Volume: 03, Issue: 03 "May - June 2020"

ISSN 2582-0176

Therefore, the null hypothesis was not rejected. This means that there was no significant difference between the mean responses of BYCOHTECH Staff and BYSSON Staff on perceived factors influencing Teaching and learning.

\subsection{Null Hypothesis 2}

There is no significant difference between mean responses of students in BYCOHTECH and BYSSON on perceived factors influencing teaching and learning.

Table 6: Summary of Independent Sample Test

\begin{tabular}{lllllllll}
\hline Variables & N & Mean & $\begin{array}{l}\text { Stand. } \\
\text { deviation }\end{array}$ & T & Df & $\begin{array}{l}\text { Sig. (2- } \\
\text { tailed) }\end{array}$ & P>.05 & Decision \\
\hline $\begin{array}{l}\text { BYCOHTECH } \\
\text { Students }\end{array}$ & 238 & 47 & 6.5 & 1.5 & 269 & .129 & Ns & $\mathrm{H}_{\mathrm{o}}$ \\
$\begin{array}{l}\text { BYSSON } \\
\text { Students }\end{array}$ & 33 & 49 & 4.1 & & & & & accepted \\
\hline
\end{tabular}

Table 6 above is observed presenting 238 respondents for BYCOHTECH Students, mean of 47 and standard deviation of 6.5 while that of BYSSON Students was 33 respondents, mean of 49 and standard deviation of 4.1. In the same vein, the table contained a ratio of 1.5, degrees of freedom of 269, P-value (Sig. for 2-tailed) of .129 at .05 alpha. This indicates that there was no significant difference between the responses of students of both Institutions. That is, the perceived factors at one institution are the same as they exist in the other Institution. This relates that the null hypothesis was not rejected.

\subsection{Null Hypothesis 3}

There is no significant relationship between perceived factors of teaching and learning among respondents

Table 7: Summary of Pearson Correlation statistics

\begin{tabular}{llllll}
\hline Pairs & $\mathbf{N}$ & Pearson r & Sig.(2-tailed) & R square & P > .05 \\
\hline Factors for 15 & .20 & .40 & .054 & NS \\
Teaching vs & & & & \\
Factors for & & & & \\
Learning & & & & \\
\hline
\end{tabular}

Table 7 above showed that a number of pairs correlated was 15 , Pearson $r$ of .20; R square of .054 and $\mathrm{P}$ value of .40 at .05 alpha for a 2-tailed significant test. Since the $\mathrm{P}$-value $(\mathrm{P}=.40)$ is greater than .05 Alpha, the null hypothesis is accepted. This means there that there is no statistically significant relationship between perceived factors influencing learning and teaching among respondents. 


\section{International Journal of Social Sciences and Management Review}

Volume: 03, Issue: 03 "May - June 2020"

ISSN 2582-0176

It has been argued that teaching and learning are crucial to the educational system of every country. Students who learn and teachers who teach are the respondents of this current study. From the demographic information, the study made use of more students (92\%) than staff (8\%). The study had more female $(64 \%)$ than males $(36 \%)$ as well while respondents from BYCOHTECH (87\%) were more than BYSSON (13\%). These demographic variables served the purpose of the study in that a proportional stratified random sampling technique was adopted to select the representative sample for the study. This censorious study had observed that there are socio-cultural, physical factors and mental factors influencing teaching and learning at a very high extent.(DaRosa, et al., 2011)in their work had similar findings that students' attitudes expectations were the greatest barrier to the implementation of critical thinking teaching strategies in that students prefer lectures over instructional strategies that require active learning. Meanwhile, this current study established that socio-cultural factors influence learning at a very high extent of $81.74 \%$, especially students' bad behaviour and action as well as students' frequent attention to night clubs affects learning at a very high extent of $87.5 \%$ and $86.7 \%$ respectively. Similarly, socio-cultural factors affect teaching as determined by the study was $74.8 \%$, a high extent.

Consequently, (Steinke \& Putman, 2007) in their study observed that there were three factors that were perceived most influential. These factors were the provision of yearly raises for all teachers, the school has resources for professional development and the school has a collaborative environment. This present study identified similar perceived factors as very influential in teaching and learning. For instance, the expertise of lecturers in the area of teaching received $86 \%$ mean response, educational environment received $83.5 \%$ and effective interaction between the lecturer and students received $90.7 \%$. We can deduce that these factors were perceived similarly in the different health institutions by the staff and students with a $\mathrm{P}>05$.

These study findings are in line with (Philip, 2007), (Boles, 2010) and (Aldelman \& Talylor, 2006) who in their various studies established teacher knowledge, classroom activities, effective feedback and effective interaction between teacher and the students. These perceived factors are as well had received high mean response rate in this current study.

One key issue this study opened up to investigate ways to allow respondents to suggest other factors perceived to be influencing teaching and learning in their institutions other than the ones under investigation. Interestingly, $90 \%$ of the respondents in their various opinion suggested similarly factors such as insecurity, poor study skills, finance, emotional stress, religious beliefs, weak parental support, poor network system, drug abuse, non-availability of recreational centres, absence of general restrooms and epileptic power supply. These individual opinions are in line with the assertions of (Boles, 2010), (Center for Mental health in schools, 2008), (DaRosa, et al., 2011), (National Research Council and the Institute of Medicine, 2004) and (Semary, 2011). In these studies, perceived factors are observed as key in the producing effective educational system. 5. Conclusion

Based on the discussion of the findings, the study indicated that factors perceived as influential to teaching and learning in health institutions in Bayelsa State are not just peculiar to the institutions but are independent of each other. However, the way they are perceived as factors suggests no significant difference in the institutions by respondents. It is obvious to 


\section{International Journal of Social Sciences and Management Review}

Volume: 03, Issue: 03 "May - June 2020"

ISSN 2582-0176

conclude that socio-cultural factors which include good relationship, students' week activities, family background, etc. influence teaching and learning in both institutions in a similar way. Also, mental factors such as heavy curriculum, time table adjustment issues, lecturer/ students classroom interaction activities etc. and physical factors such as classroom/office space, teaching aids, absence of library/ ICT facilities etc. are identified factors that influence teaching and learning in Health Institutions in Bayelsa State.

\subsection{RECOMMENDATIONS}

Following the conclusion deduced above, it is crystal clear that the findings of the study will be implicated on the teachers/lecturers, students, government, NGOs, Examining Boards. Therefore, these perceived factors influencing teaching and learning could be used by institutions, government, NGO, examining boards, etc. to develop and plan the education system, especially as it affects health. Overcoming strategies be put in place by all stakeholders of health institutions. To this, therefore, the following recommendations are made:

- Manpower development should be based on areas of specialization related to available training professions.

- Motivation of lecturers in the form of good offices, quarters, regular salary payment, etc. is vital to overcoming some of these factors observed.

- Government should partner with the private sector to allocate adequate space, budgets for supplies, professional resources, equipment and overheads to health institutions.

- Planners of the curriculum should build systems into the curriculum that will increase the capacity for teacher-learner relationships.

- Respective program regulatory agencies/boards should develop global health care professions institute whose aim would be to advance the development of health professions educators and educational research.

\section{REFERENCES}

Aldelman, H., \& Talylor, L. (2006). The implementation guide to student learning supports: New directions for addressing barriers to learning. Thousand Oaks, CA: Corwin Press.

Bear, G. G. (2008). School-wide approaches to behaviour problems. In B. Doll, \& J. A. Cummings, Transforming school mental health services. Thousand Oaks, CA: Corwin Press.

Bell, M. J. (n.d). Retrieved from Define academic performance: www.ehow.com>ehow>education

Boles, W. (2010). Overcoming barriers to learning: Aguide for academics. Australia: QUT. Center for Mental health in schools. (2008). Addressing Barriers to learning. Mental Health in Schools, 13(2), 1-7.

Coon, D. (2003). Essentials of psychology, 9th edition. New York: Worth Publishers. 


\section{International Journal of Social Sciences and Management Review}

Volume: 03, Issue: 03 "May - June 2020"

ISSN 2582-0176

DaRosa, D. A., Skeff, K., Friedland, M. D., Coburn, M., Cox, S., Pollart, M. D., et al. (2011). Barriers to effective teaching. Academic Medicine, 86(4), doi:10.1097/ACM.0b013e31820defbe , 1-7.

Edoghotu, J. S., \& Adu, J. G. (2014). Effective study skills for optimum performance in examinations: A guide to students and teachers. Port Harcourt: alheribooks.

Federal Republic of Nigeria. (2004). National Policy on Education, 2nd edition. Lagos: Ministry of Information.

Friedland, J. A. (2002). Social learning theory and the development of clinical performance. In J. C. Edwards, J. A. Friedland, \& R. Bing-You, Residents teaching skills (pp. 18-37). New York, NY: Springer.

Gardner, T. (1993). Assessment as a tool of educational measurement . Journal of Educational Psychology, 5 , 3-9.

Gibbs, G., \& Simpson, C. (2005). Conditions under which assessment supports students' learning. Learning and Teaching in Higher Education, 1, 3-31.

Irby, D. M., Cooke, M., \& O'Brien, B. C. (2010). Calls for reform of medical education by the Carnegie foundation for the advancement of teaching: 1910 and 2010. Acad. Med., $85,220-227$.

Mayor, M. (2009). Longman dictionary of contemporary english 5th edition. UK: Pearson Education.

National Research Council and the Institute of Medicine. (2004). Engaging schools: Forstering high school students' motivation to learn. Washington, DC: National Academic Press.

Oladokun, V. O., Adebanjo, A. J., \& Charles-Owaba, O. E. (2008). Predicting students' academic performance using artificial neural network: A case study of an engineering course. . The Pacific Journal of Science and Technology, 9(1) , 72-79.

Onuebunwa, S. E. (1999). Educational Technology: An introduction. Owerri: CAPE PUBLISHERS.

Philip, G. (2007). Five factors for effective teaching. New Zealand Journal of Teachers' Work, 4(2), , 89-98.

Queensoap, M. (2014). Application of diffrential item functioning in detecting item bias in chemistry achievement test in Nigeria. PortHarcourt: College of graduate studies, University of PortHarcourt.

Race, P. (2005). Making learning happen: A guide for post-compulsory education. Thousand Oaks, CA: Sage Publications. 


\section{International Journal of Social Sciences and Management Review}

Volume: 03, Issue: 03 “May - June 2020”

ISSN 2582-0176

Semary, H. E. (2011). Barriers to the effective use of technology in education: Case study of UAE University. Asian Transactions on Science \& Technology (ATST ISSN:2214283), 1(5), 22-32.

Steinke, L. J., \& Putman, A. R. (2007). Why should i stay? Factors influencing technology education teachers to stay in teaching positions. Journal of Technology Education, 19(1), 71-84.

Strokes, A. K. (2007). Research in science education: Threshold concepts. Journal of Geoscience Education, 55(5) , 434-438.

Vermunt, J. D., \& Verloop, N. (1999). Congruence and friction between learning and teaching. Learning and Instruction, 9(3), 257-280.

Vogt, C. M. (2008). Faculty as a critical juncture in student retention and performance in engineering programs. . J ournal of Egineering Education, 97(1), 27-36.

Warash, J. (1996). The place of learning aids in Nigeria education. West African Journal of Education, 3(2) , 23-27.

Ward, A., Stoker, W. H., \& Murray-Ward, M. (1996). Achievement and ability test definition of domain. Edecational Measurement, 2. , 2-5. 